\title{
柿ポリフェノールの耐光性改善
}

\author{
織田 博則*1,\#
}

\section{Improving the Light Fastness of a Kaki Polyphenol}

\author{
Hironori Oda ${ }^{* 1, \#}$ \\ Faculty of Education, Osaka Kyoiku University, \\ 4-698-1 Asahigaoka, Kashiwara, Osaka 582-8582, Japan
}

\begin{abstract}
The photofading behavior of a Kaki polyphenol on cellulose was investigated. The contribution of autooxidation, singlet oxygen and superoxide ion to that fading was suggested. Various nickel arylsulfonates were prepared, and the protecting effect of these nickel salts was examined towards this color. The photofading rate was remarkably suppressed in the presence of nickel salts, while the addition of UV absorbers and conventional stabilizers afforded little retardation of the rate of fading.

The effect of the representative compounds against the fading of this color has also been examined on cotton fabrics. The results provided a valuable method for improving the light fastness of dyed fabrics. It was proposed that nickel complexes of 1-naphtol-8-sulfonic acid and its derivatives can be applied as effective stabilizers against the fading of a Kaki polyphenol.
\end{abstract}

(Received 4 July, 2012 ; Accepted 5 September, 2012)

\section{1. 緒 言}

1856 年イギリスのパーキンにより塩基性染料モーブが 合成されるまでは，衣食住の日常生活の中での色は，天 然色素を用いてきた．植物に由来する色素としては栃子, 紅花，うこん，動物に由来する色素はコチニール，ラッ ク色素などがあり，父から息子へ，母から娘へと長年受 け継がれてきたが, 合成色素の出現により数多くの染料 が市場に出てくると, 安価で鮮明で堅ろう性のよい合成 色素が繊維，塗料用に限らず，食用も含めて完全に天然 物に代替されてしまった。我が国で言えば，明治時代か ら大正, 昭和の第二次世界大戦前まで合成染料が中心で あり，今では特定化学物質に認定されているオーラミン も着色剂として使用されていた。更に大戦後はアメリカ ナイズされることにより合成染料の全盛期となったが, 公害問題と共に 1965 年には従来合成色素として指定され た物の一部削除や, 使用基準の設定, 表示義務等, 法の 改正があり，再び天然色素に注目が集まっている。しか し天然色素を繊維, 食品着色用として用いるには種々の 問題がある。1)鮮やかな色彩がない，2)安全性のデー夕 がない, 3) 産地, 気候の変動による品質のバラつきが大 きい, 4) 原料を大量に使用することからの廃棄処理問題,

\# corresponding author

*1 大阪教育大学教育学部
5)単一成分からなるものが少なく分析や品質管理の問題, 6)色価が低く，コスト高である，7）異種色素との配合, 染色が困難である，8)光, 熱, 酸に不安定である $[1]$. な どの問題があるが, 天然色素使用の最大の問題点は光不 安定性であり, この問題の解決が実用化, 特に繊維業界 への進出を図る第一歩である.ここでは天然色素モデル として柿渋(ポリフェノール)を用い, 耐光性の改善を試 みた。

\section{2. 実 験}

\section{1 材 料}

柿渋(柿ポリフェノール) $\left(\lambda_{\max } 460,275,224 \mathrm{~nm}\right)$ は石井 物産 KK 製の粉末を使用した。 2,6-ジ-t-ブチル- $p$-クレゾー ル (HP)，1,4-ジアザビシクロ $[2 ， 2 ， 2]$ オタン (DABCO)， ポリスチレンスルホン酸ナトリウム, 亜硫酸ナトリウム, ローズベンガル (CI Acid Red 94) ( $\left.\lambda_{\max } 562,521 \mathrm{~nm}\right)$ は和光 純薬 $\mathrm{kk}$ から購入した. ベンゾフェノン系紫外線吸収剂 2-ヒドロキシベンゾフェノン $(\mathrm{HBP})\left(\lambda_{\max } 335,260 \mathrm{~nm}\right)$ 及び ベンゾトリアゾール系紫外線吸収剤 2-(2'-ヒドロキシ-5'メチルフェニル)ベンゾトリアゾール $(\mathrm{HBT})\left(\lambda_{\max } 340\right.$, $330 \mathrm{~nm})$ は東京化成 $\mathrm{kk}$ から購入し精製して用いた.

一連のフェニルエステル系化合物は文献に従い, 対応 するフェノールおよびナフトール誘導体に塩化ベンゾイ ルを作用させ，ベンゾイル化して合成，50\%酢酸による 
再結晶品を用いた $[2]$. 各種夕イプの異なるニッケル錯体 は文献に従い合成し精製した[3]. HBT のスルホン化も文 献に従い合成後 $[4]$, ニッケル塩化を行った.

\section{2 柿渋の光退色挙動}

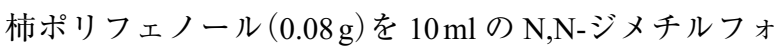
ルムアミド-水 $(1: 9, \mathrm{v} / \mathrm{v})$ 混合溶液に $80^{\circ} \mathrm{C}$ で 1 時間擋拌 することにより調整した。 また, 紫外線吸収剂やニッケ ル錯体及び各種添加物 $\left(2 \times 10^{-2} \mathrm{~mol} / \mathrm{l}\right)$ を含む柿ポリフェ ノール溶液についても, 同様に調整した，その調整液 $30 \mu 1$ を tlc セルロース板上にマイクロシリンジを用い滴下, 乾 燥した. 作成された tlc セルロース板に Solar Box (1500e, CO.FO, ME.GRA S.r.l., イタリア製)を用い, キセノンアー ク灯 $\left(550 \mathrm{~W} / \mathrm{m}^{2}\right)$ を $65^{\circ} \mathrm{C} て ゙ ~ 60$ 時間照射した. 照射後の tlc

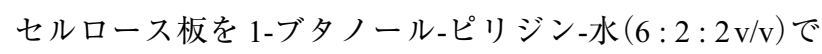
$15 \mathrm{~cm}$ 展開し, 乾燥後, 分離された色素スポット濃度を薄 層クロマトスキャナー(CS-920, 島津製作所製)を用い測 定し, 同様な方法で展開した未照射色素スポット濃度と 比較することにより退色率を求めた。

\section{3 柿渋染色綿布の作成と耐光性評価}

綿布には，JIS 染色堅ろう度試験用(JIS L 0803 準拠)の 単一繊維綿布を使用した。水酸化ナトリウム $10 \mathrm{~g} / 1$ と濃度 が $5 \mathrm{~g} / 1$ のグリシジルトリメチルアンモニウムクロライド 水溶液 (カチオン化剂) に, 水溶液 11 当り $50 \mathrm{~g}$ 相当の綿布 を $70^{\circ} \mathrm{C}$ で 30 分間浸漬しカチオン化処理し $0.2 \%$ 酢酸水溶

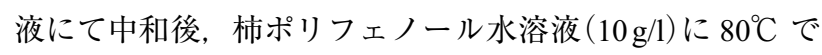
1 時間染色処理を行った. 次に, 各種安定化剂の $5 \mathrm{~g} / 1$ 水 溶液を調整し, これらに, それぞれ, 先に染色処理した

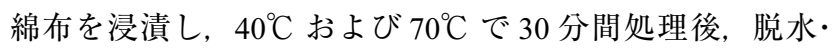
自然乾燥した。

耐光性試験には，JIS L 0824 に対応したスガ試験機 kk 製FAL-5 型フェードテスターを使用した。耐光性試験は 未照射時の染色布とカーボンアーク灯 200 時間光照射後 の染色布の色差 $\left(\Delta E^{*} a b\right)$ を, 分光測色計 $\mathrm{SC}-\mathrm{T}$ (スガ試験機 kk) を用いて測定し, JIS L 0809(2001)に従い, 染色布の 変退色用グレースケール対応計測值 $\mathrm{Nc}^{\#}$ から等級への変換 を行った。

\section{3. 結果及び考察}

\section{1 柿ポリフェノールの光退色速度に及ぼす添加物 の効果}

色素の光退色と化学構造との関係は, 以前から数多く の研究結果が集積されており, 光退色は, 空気中におい ては一般に酸化に起因して起こり, 毛のように基質が色 素より酸化されやすい場合には還元反応が起こる可能性 があり, 一部のクマリン系やスチルベン系色素において は二量化や異性化の寄与も指摘されている $[5,6]$.

色素の光退色における酸化反応については, 自動酸化, 一重項酸素酸化, スーパーオキシドイオン酸化の寄与が 見出されている. 参考のために, 図 1 に色素の光退色機
構と (作用する光の種類), [光安定化㓱]を示した.

自動酸化は紫外線照射やラジカル開始剤が退色を促進し, 自動酸化防止剂や紫外線吸収剂が退色を抑制する。一方, 一重項酸素による酸化は, 色素の励起三重項状態エネル ギーを基底状態の酸素分子に移行することにより生成し た一重項状態の酸素活性種が酸化剂となり退色が進む. この反応の特徵は可視光照射によっても退色が進むこと であり, ローズベンガルなどの一重項酸素増感剤の添加 で退色が加速され, 自動酸化防止剂では効果がないが DABCO などの一重項酸素脱活性化剂が退色を抑制する. また, スーパーオキシドイオンによる酸化を抑制するに は覀硫酸ナトリウム(スーパーオキシドイオン脱活性化 剤) などが有効であるとされている [9].

柿ポリフェノールは柿に含まれる柿タンニンのことで, 柿タンニンはカテキン類の内エピカテキン, カテキンガ レート, エピガロカテキン, ガロカテキンガレートが 1 : $1: 2: 2$ の比率で 12 30 分子縮合した分子量 15000 程度の

\begin{tabular}{|c|c|}
\hline \multirow{3}{*}{ Oxidation } & $\begin{array}{l}\text { Autoxidation (UV light photofading) } \\
\text { [Antioxidants][UV absorbers] }\end{array}$ \\
\hline & $\begin{array}{l}\text { Singlet oxgen Oxidation } \\
\text { (UV and Visible light photofading) } \\
\text { [Singlet oxgen Quenchers] }\end{array}$ \\
\hline & $\begin{array}{l}\text { Superoxide ion Oxidation } \\
\text { [Superoxide ion Quenchers] }\end{array}$ \\
\hline
\end{tabular}

Reduction

Dimerization

Isomerization

Fig. 1 Photofading mechanism of color and [stabilizers].

Table 1 Effect of various additives on the photofading of Kaki polyphenol.

\begin{tabular}{cccc}
\hline Run & Additive & $\begin{array}{c}\text { Add. concn. } \\
\left(\times 10^{-2} \mathrm{~mol} / \mathrm{l}\right)\end{array}$ & $\begin{array}{c}\text { Photofading }{ }^{1)}(\%) \\
\text { after } 60 \mathrm{~h}\end{array}$ \\
\hline 1 & none & - & 59 \\
2 & $\mathrm{HP}^{2)}$ & 2 & 56 \\
3 & $\mathrm{HBP}^{3)}$ & 2 & 48 \\
4 & $\mathrm{HBT}^{4)}$ & 2 & 48 \\
5 & Rose Bengal $_{6}$ & 2 & 60 \\
6 & DABCO & 2 & 55 \\
7 & Sodium sulfite & 2 & 43 \\
\hline
\end{tabular}

1) Color $(0.08 \mathrm{~g} / 10 \mathrm{ml})$, on tlc cellulose plate $(30 \mu \mathrm{l} \mathrm{spot})$, xenon arc lamp irradiation, $\lambda=460 \mathrm{~nm}$ scan.

2) 2,6-di-t-butyl-p-cresol. 3) $o$-hydroxybenzophenone.

4) 2-(2-benzotriazoryl)-p-cresolsulfonate sodium salt 
高分子色素とされているが, 現在まだ正確な化学構造等 は不明である $[10]$. その為, ここでは上記光化学的知見 に基づく添加物の効果から, 光退色機構の追及を試みた.

表 1 には綿布を想定した tlc セルロース板上に柿ポリ フェノールをスポットし, キセノンアーク灯 $\left(550 \mathrm{~W} / \mathrm{m}^{2}\right.$, $\left.65^{\circ} \mathrm{C}\right)$ を 60 時間照射した時の退色率と添加物の効果を示 した．まず，柿ポリフェノール自身の退色はキセノンアー ク灯を 60 時間照射した場合，59\%退色するのに対し，自 動酸化防止剂 (HP) を添加した場合には，その退色は $56 \%$ と僅かな抑制が見られ, 一重項酸素増感剤であるローズ ベンガル添加の系では, 退色率は $60 \%$ と僅かな加速が見 られ, 一重項酸素脱活性化剂 (DABCO)の添加の系では,

退色は $55 \%$ に抑制されている. 一方, 亜硫酸ナトリウム 添加の系では, 柿ポリフェノールの退色は $43 \%$ と 16 ポイ ント低下の大きな抑制が見られる。このことから, 柿渋 の光退色は, 自動酸化と一重項酸素酸化の寄与に加えて, スーパーオキシドイオンによる退色が示唆される.

また, ベンゾフェノン $(\mathrm{HBP})$ およびベンゾトリアゾー ル系紫外線吸収剂 (HBT)の添加の系でも大きな退色の抑 制効果が見られている. この事実は, 柿渋は可視部領域 の吸収 $\left(\lambda_{\max } 460 \mathrm{~nm}\right)$ に比べ, 紫外部における大きな吸収 $\left(\lambda_{\max } 275,224 \mathrm{~nm}\right)$ を有していることに起因するものと考 えられる。

\section{2 柿ポリフェノールの光退色に及ぼすニッケルア リールスルホン酸塩の効果}

合成染料の光退色に及ぼす一重項酸素の役割は溶液中 と固相上で報告されており, ニッケルスルホン酸基を有 する染料は可視光照射下において優れた光安定化効果を 示した[11]. また, ニッケル $p$-トルエンスルホン酸塩 $\left(\mathrm{NTS}: \lambda_{\max } 233 \mathrm{~nm}\right)$ やニッケルアリールスルホン酸塩はナ イロン染色布における合成染料の耐光性を著しく向上さ せた[12]. 一方, 天然色素についても, 光退色に及ぼす 一重項酸素酸化の寄与が示唆された紅花赤色素カルタミ ンの耐光性をニッケルアリールスルホン酸塩は効率よく 改善した[13]. 更に, メチレンブルーを用いた実験より， ニッケル錯体は亜硫酸ナトリウムと同様, 効率よくスー パーオキシドイオンを脱活性化することも知られている [14].

上記理由により, 柿ポリフェノールの耐光性改善を目 的とした，ニッケルアリールスルホン酸塩類の使用は興 味が持たれる. 表 2 には tlc セルロース板上での柿ポリ フェノールの光退色に及ぼすニッケルアリールスルホン 酸塩の効果を塩化ニッケル添加の系(Run 8) と共に示した. セルロース上での柿ポリフェノールにキセノンアーク 灯 $\left(550 \mathrm{~W} / \mathrm{m}^{2}, 65^{\circ} \mathrm{C}\right)$ を 60 時間照射した時の色素自身の退 色は $59 \%$ あるあのに対し, ニッケル $p$-トルエンスルホン 酸塩 (NTS) [12]添加の系では, その退色は 54\%と僅かな 抑制が示されるのみであった. 同様な傾向は, ニッケル ポリアルキルアリールスルホン酸誘導体についても見ら れ, 僅かにニッケル 2,5-キシレンスルホン酸塩(Run 4)が
Table 2 Effect of various nickel salts on the photofading of a Kaki polyphenol.

\begin{tabular}{cccc}
\hline Run & Nickel salt & $\begin{array}{c}\text { Add. } \\
\text { concn }^{1)}\end{array}$ & $\begin{array}{c}\text { Photofading (\%) } \\
\text { after } 60 \mathrm{~h}^{2)}\end{array}$ \\
\hline 1 & none & - & 59 \\
2 & $p$-Toluenesulfonate & 2 & 54 \\
3 & 2,4 -Xylenesulfonate & 2 & 57 \\
4 & 2,5 -Xylenesulfonate & 2 & 49 \\
5 & Mesitylenesulfonate & 2 & 53 \\
6 & Naphthalene-2,6-disulfonate $^{2}$ & 42 \\
7 & Polystyrene-4-sulfonate $^{2} 0.4 \mathrm{~g}^{3)}$ & 0 \\
8 & $\mathrm{NiCl}_{2} \cdot 6 \mathrm{H}_{2} \mathrm{O}^{4)}$ & 2 & 57 \\
\hline
\end{tabular}

1) Nickel salt concentration $\left(\times 10^{-2} \mathrm{~mol} / \mathrm{l}\right)$.

2) irradiated on the same condition as Table 1.

3) unknown molecular weight.

4) Nickel(II) chloride hexahydrate.

10 ポイント程度の抑制効果を示すのみであった。 この事 から, 安定化剤としての芳香環へのメチル基の導入は柿 ポリフェノールの耐光性改善には, ほとんど効果がない ことが示唆された. 一方, ナフタレン-2,6-ジスルホン酸 塩(Run 6) やポリスチレンスルホン酸塩(Run 7) は顕著な退 色の抑制効果を示し, 特にポリスチレンスルホン酸のニッ ケル塩は柿ポリフェノールの退色を完全に防止した。こ の事から, 安定化剤へのニッケルスルホン酸基の導入は 柿ポリフェノールの耐光性改善には有効な構造改変であ ることが示唆される.

\section{3 光安定化剂への置換基導入効果}

天然酸化防止剂中の抗酸化成分はカフェイン酸の様に, いずれもフェノール性水酸基を有しており, 活性な自動 酸化防止効果を有していることはよく知られている $[15]$. また, フェノール性水酸基を有するアリールスルホン酸 のニッケル錯体は, 紅花赤色素カルタミンの退色を効率 よく抑制している[13]. その為, ここではニッケルヒド ロキシアリールスルホン酸塩の効果を, 先と同様な条件 下で検討した．結果を表 3 に示す.

安定化剂としては, フェノールスルホン酸塩に比べ, ナフトール誘導体において優れた抑制効果が見られ, ニッ ケル 1-ナフトール-4-スルホン酸塩添加の系(Run 4)では, 柿ポリフェノールの退色を $1 / 5$ に抑制し, 1-ナフトール-8スルホン酸塩(Run 6)では, 完全に色素の光退色を防止し ている. 一方, 1,7-ジヒドロキシナフタレンスルホン酸塩 添加の系(Run 9)では, 柿ポリフェノールの退色は, まだ $26 \%$ 程度見られている. この様な傾向は紅花赤色素につ いても見られていることから [13], 天然色素の光安定化 剤としては, 数多くの水酸基の導入は, 耐光性改善には 不利に働くことが示唆された.

フェニルエステル系紫外線吸収剤は紫外線を吸収し, 
Table 3 Effect of various nickel salts on the photofading of a Kaki polyphenol.

\begin{tabular}{|c|c|c|c|}
\hline Run & Nickel salt & $\begin{array}{l}\text { Add. } \\
\text { concn }^{.1)}\end{array}$ & $\begin{array}{c}\text { Photofading }(\%) \\
\text { after } 60 \mathrm{~h}^{2)}\end{array}$ \\
\hline 1 & none & - & 59 \\
\hline 2 & $p$-Phenolsulfonate & 2 & 50 \\
\hline 3 & 1-Naphthol-3-sulfonate & 2 & 36 \\
\hline 4 & 1-Naphthol-4-sulfonate & 2 & 12 \\
\hline 5 & 1-Naphthol-5-sufonate & 2 & 36 \\
\hline 6 & 1-Naphthol-8-sulfonate & 2 & 0 \\
\hline 7 & 2-Naphthol-6-sulfonate & 2 & 26 \\
\hline 8 & 2-Naphthol-7-sulfonate & 2 & 30 \\
\hline 9 & $\begin{array}{l}\text { 1,7-dihydroxynaphthalene- } \\
\text { 3-sulfonate }\end{array}$ & 2 & 26 \\
\hline
\end{tabular}

1) Nickel salt concentration $\left(\times 10^{-2} \mathrm{~mol} / \mathrm{l}\right)$.

2 ) irradiated on the same condition as Table 1.

光 Fries 転移を起こし, ベンゾフェノン系紫外線吸収剤を 式(1)に見られるような反応により生成し, 紫外光を吸収 し続けることはよく知られている $[8]$. そこで, 表 3 に示 したフェノール及びナフトール誘導体をベンゾイル化す ることにより，対応するフェニルエステル系誘導体を合 成し，先と同様な条件下，柿ポリフェノールの光退色抑 制効果を検討した。その結果を表 4 に示した。比較のた めにベンゾフェノン系紫外線吸収剤 2-ヒドロキシ-4-メト キシベンゾフェノン-5-スルホン酸のニッケル塩(Run 6)に ついても, その効果を併せて検討した.

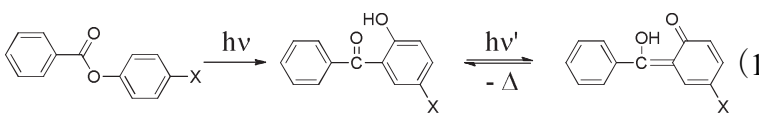

ヒドロキシアリールスルホン酸塩添加の系に比べ, 表 4 に示したベンゾイル化した化合物は一般に, 光退色の抑 制効果は劣っている. この事は, 柿ポリフェノールは高 分子色素であるため, バルキーなベンゾイル基を安定化 剤に導入することにより, 安定化剂の色素への侵入が阻 止された為ではないかと推察される。この仮説は, ジ置 換体添加の系(Run 5)が， モノ置換体添加の系 (Run 3，4) に比べ，抑制効果が劣っていることからも支持されるか もしれない. ポリスチレン-4-スルホン酸ニッケル塩も高 分子物質である為バルキーであるがニッケルスルホン酸 基を数多く有している為, 前節で述べた数多くのニッケ ルスルホン酸基の効果によると考えているが, 詳細は検 討中である.

また，ニッケル 1-ベンゾイロキシナフタレン-8-スルホ ン酸塩(Run 4)が僅かにベンゾフェノン系紫外線吸収 (Run 6)より優れた効果を保持していた以外には，一般に耐光 性改善効果に劣っている.この事は光フリース転移によ
Table 4 Effect of various nickel salts on the photofading of a Kaki polyphenol.

\begin{tabular}{cccc}
\hline Run & Nickel salt & $\begin{array}{c}\text { Add. } \\
\text { concn }^{1)}\end{array}$ & $\begin{array}{c}\text { Photofading (\%) } \\
\text { after } 60 \mathrm{~h}^{2)}\end{array}$ \\
\hline 1 & none & - & 59 \\
2 & $\begin{array}{c}\text { 4-Benzoyloxybenzene- } \\
\text { sulfonate }\end{array}$ & 2 & 55 \\
3 & $\begin{array}{c}\text { 1-Benzoyloxynaphthalene- } \\
\text { 3-sulfonate }\end{array}$ & 2 & 40 \\
4 & $\begin{array}{c}\text { 1-Benzoyloxynaphthalene- } \\
\text { 8-sulfonate }\end{array}$ & 2 & 28 \\
5 & $\begin{array}{c}\text { 1,7-Dibenzoyloxynaphtha- } \\
\text { lene-3-sulfonate }\end{array}$ & 2 & 56 \\
3 & $\begin{array}{c}\text { 2-hydroxy-4-methoxybenzo- } \\
\text { phenone-5-sulfonate }\end{array}$ & 2 & 36 \\
\hline
\end{tabular}

1) Nickel salt concentration $\left(\times 10^{-2} \mathrm{~mol} / \mathrm{l}\right)$.

2) irradiated on the same condition as Table 1.

るベンゾイルラジカルの転移効率の悪さによるものかも 知れない $[16]$.

\section{4 綿染色布の耐光性}

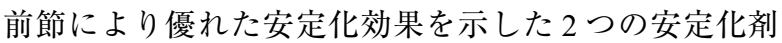
について, 柿ポリフェノール染色綿布の安定化剂処理条 件と 200 時間カーボンアーク灯を照射した時の色差及び 日光堅ろう度を JIS L 0809(2001) 規格に従い, グレース ケールで判定した. 結果を表 5 に示す。 まず, 柿ポリフェ ノール染色綿布はカーボンアーク灯を 200 時間照射する ことにより，著しい退色が見られ，色差 $\left(\Delta \mathrm{Eab}^{*}\right)$ は 20.54 と殆ど退色してしまい, グレースケール評価による耐光 性は 1-2 級であった. しかし，ニッケル1-ナフトール-8スルホン酸塩を $40^{\circ} \mathrm{C} て ゙ 30$ 分処理した染色布の $\Delta \mathrm{Eab} *$ は 4.13 で耐光性は 4-5 級と非常に優れた耐光性を示した。 ま

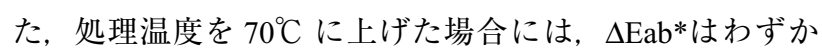
に大きな值を示すことから, 高温処理は安定化剤の付着

Table 5 Light fastness of Kaki polyphenol on cotton fabrics treated with nickel salts.

\begin{tabular}{ccccc}
\hline Run & Nickel salt ${ }^{1)}$ & Treatment $^{2)}$ & D Eab $^{* 3)}$ & Lf $^{4}$ \\
\hline 1 & none & - & 20.54 & $1-2$ \\
2 & 1-Naphthol-8-sufonate & $40{ }^{\circ} \mathrm{C}, 30$ min. & 4.13 & $4-5$ \\
3 & 1-Naphthol-8-sulfonate & $70{ }^{\circ} \mathrm{C}, 30$ min. & 4.71 & $4-5$ \\
4 & Polystyrene-4-sulfonate & $40{ }^{\circ} \mathrm{C}, 30$ min. & 4.40 & $4-5$ \\
\hline
\end{tabular}

1) $10 \%$ owf. 2) Treated condition with nickel salt. 3) $200 \mathrm{~h}$ irradiation (carbon arc light, $100 \mathrm{~kW} / \mathrm{m}^{2}, 80^{\circ} \mathrm{C}$ ). 4) Gray scale, JIS L 0809 (2001). 
Table 6 Light fastness of a Kaki polyphenol on cotton fabrics.

\begin{tabular}{|c|c|c|c|}
\hline $\begin{array}{l}\text { Irradiated } \\
\text { for } 200 \mathrm{~h} \\
\text { (Carbon } \\
\text { arc light) }\end{array}$ & & & \\
\hline $\begin{array}{l}\text { Treated } \\
\text { condition }\end{array}$ & no treated & $\begin{array}{l}\text { treated with } \\
\text { nickel 1- } \\
\text { naphthol-8- } \\
\text { sulfonate at } \\
\quad 40^{\circ} \mathrm{C}\end{array}$ & $\begin{array}{l}\text { treated with } \\
\text { nickel 1- } \\
\text { naphthol-8- } \\
\text { sulfonate at } \\
\quad 70^{\circ} \mathrm{C}\end{array}$ \\
\hline
\end{tabular}

性の低下を招くものと考えられる. その為, ニッケルポ リスチレンスルホン酸塩については, Run 2 と同様な条件 下で処理を行った。 その結果, 予備実験と同様, 優れた 耐光性の向上が見られ, 染色布の耐光性は 4-5 級と, 200 時間カーボンアーク灯を照射しても, 殆ど綿染色布の退 色は見られていない.

また, 参考に, ニッケル 1-ナフトール-8-スルホン酸塩 で処理した柿ポリフェノール染色綿布にカーボンアーク 灯を 200 時間照射した時の染色布を未処理染色布と共に 表 6 に示した。

上記知見から，1-ナフトール-8-スルホン酸及びポリス チレン-4-スルホン酸のニッケル塩を柿ポリフェノールの 耐光性改善処理剤の 1 つとして提案する.

\section{4. 結 論}

柿渋の生活環境材料としての有効利用を目的として, 天然色素の致命的欠点である耐光性の改善を試みた。

まず, 基礎研究により柿ポリフェノールの光退色は自動 酸化, 一重項酸素酸化及びスーパーオキシドイオン酸化 の寄与があることを添加物の効果から見出された.

一重項酸素とスーパーオキシドイオンの脱活性化機能 を併せ持つニッケルアリールスルホン酸塩が柿ポリフェ ノールの光退色を抑制した. しかし, フェニルエステル 基のようなバルキーな置換基の安定化剤への導入は耐光 性改善には不利に働くことが示唆された. 綿染色布を用 いた日光堅ろう度試験により, ニッケル 1-ナフトール-8スルホン酸塩やポリスチレン-4-スルホン酸塩を柿渋着色 資材の耐光性改善剤の 1 つとして提案した.

\section{謝 辞}

柿渋染色布の耐光性試験について奈良県工業技術セン ターに感謝の意を表する。

\section{文 献}

1. For example, H. Zollinger, "Color Chemistry", WILEYVCH, Weinheim, (2003). K. Hunger, "Industrial Dyes", WILEY-VCH, Weinheim, (2003). Y. Hosoda, "Sin Senryo Kagaku”, Gihoudo Tokyo (1963). H. Horiguchi, "Sougou Gouse Sennryou”, Sannkyo, Tokyo (1970). H. Tanimura etal., "Ten-nen Chakusyokuryo Hadbook", Korin, Tokyo (1979). T. Shimizu and M. Nakamura, "Sinpan Syokuyo Ten-nen Sikiso", Korin, Tokyo (2001).

2. R. A. Finnegan and J. J. Mattice, Tetrahedron, 21, 2015 (1965).

3. H. Oda and T, Kitao, J. Soc. Dyers Colour., 101, 177 (1985).

4. I. H. Leaver, P. J. Waters and N. A. Evans, J. Polym. Sci., Polym. Chem. Ed., 17, 1531 (1979).

5. N. S. Allen and J. F. Mckellar, "Photochemistry of Dyed and Pigmented Polymers", Applied Science Publishers, London (1980).

6. H. Oda, N. Kuramoto and T. Kitao, J. Soc. Dyers Colour., 97, 462 (1981).

7. J. Griffiths, "Developments in the Chemistry and Technology of Organic Dyes", Society of Chemical Industry, London (1984).

8. J. E. Kresta, "Polymer Additives", Plenum Press, New York (1984).

9. R. Gachter and H. Muller, "Plastics Additives Handbook", Hauser Publishers, London (1993).

10. T. Matsuo and S. Ito, Agric. Biol. Chem., 42, 1637 (1978).

11. H. Oda and T. Kitao, J. Soc. Dyers Colour., 102, 305 (1986).

12. H. Oda, Color. Technol., 121, 216 (2005).

13. H. Oda, Color. Technol., 117, 204 (2001).

14. N. Kuramoto and T. Kitao, J. Soc. Dyers Colour., 98, 159 (1982).

15. R. A. Larson, Phytochemistry, 27, 969 (1988).

16. J. Yamamoto, M. Haraguchi, T.Yamamoto and H.Sasaki, Nihon Kagakukaishi, 1996, 909. 